\title{
SZEMLE
}

Educatio 28 (3), pp. 624-627 (2019)

DOI: $10.1556 / 2063.28 .2019 .3 .15$

\section{MEGELŐZŐ SZEMLÉLET \\ A TELJESÍTMÉNYKÉNYSZER KULTÚRÁJÁBAN}

\author{
SIEGLER ANNA \\ Pécsi Tudományegyetem, Pszichológia Doktori Iskola
}

Kris Bosworth (ed.): Prevention Science in School Settings: Complex Relationships and Processes (Advances in Prevention Science). New York, Springer, 2015. vii + 376 p.

ISBN 978-1-4939-3155-2 (eBook)

Miként távolíthatjuk el az eredményes tanulás lehetséges akadályait? A jó gyakorlatok hogyan tarthatóak fent hosszú távon? A Kris Bosworth gondozásában megjelent kötet összesen tizenhét tanulmányt egyesít, bemutatva az iskolai prevenció tudományos palettáját, a sikeres programbevezetés és minőségi fenntarthatóság elemeit. Közös kimondatlan egyezség a szerzők között, hogy míg a kamaszkor a felnőtt szerepek kipróbálásának időszaka, addig az iskola feladata, hogy a lehető legbiztonságosabb teret nyújtsa ezen periódus során. A drogok használata, az agreszszív viselkedési repertoár berögződése, a korai szexuális tapasztalatok és az iskola idő előtti elhagyása megnehezíti a tanulási folyamatokat, azonban a kutatók és az iskolai kontextusban dolgozó szakemberek együttmüködéséből fakadó programok képesek az akadályt jelentő viselkedések megjelenését csökkenteni. A tanulmánykötet az amerikai oktatáspolitika környezetének tárgyalása után részletesen bemutatja a szakmai kooperációk különböző résztvevőinek szerepét, a programok fej- lesztésének, implementációjának és fenntarthatóságának bevált praktikáit és gyakorlatban megvalósuló példáit.

A kontextus meghatározása azért is fontos e kötet olvasásának szempontjából, mivel szinte minden tanulmány reflektál a rendszerszinten megjelenő teljesítménynyomás kultúrájára. Terell Bell amerikai oktatási miniszter széles körben elhíresült Veszélyben a nemzet (A Nation at Risk) címü 1983-as jelentésével reflektorfénybe helyezte az oktatás színvonalnövelésének szükségességét. Az ország gazdasági versenyképessége érdekében átfogó reformjavaslatokat szorgalmazott: javasolta, hogy növeljék meg a tanulók iskolában eltöltött idejét, szigorítsák az érettségi feltételeit, és folyamatos standardizált tesztekkel biztosítsák a minőségi fejlődést. A propagált tanárképzési változtatások a tanítási technikák egységesítésével kevesebb egyéni szabadságot hagytak a pedagógusoknak, ami a sztenderdmozgalom kritikusai szerint kevesebb kollaborációhoz, erősebb bürokratikus működéshez vezetett. A 2000-es évek elején érvénybe lépő 
No Child Left Bebind (NLCB) törvény az elszámoltathatóság elve mentén csökkenteni szándékozta az esélyegyenlőtlenségből fakadó teljesítménykülönbséget. Az egységes elvárásoknak való megfeleltetés változtatásra készteti azokat az iskolákat, amelyek tanulói nem érik el a sztenderd teljesítményt a főbb tantárgyak felmérésekor, és így csökkentik a hátrányos és nem hátrányos helyzetü diákok közötti különbségeket. A törvény kritikusai szerint azonban az, hogy a sztenderd teszteken rosszabbul teljesítő iskolák büntetésben részesülnek, megbélyegző és demoralizáló. A fejlesztés nem holisztikus, hanem tesztorientált, sok pedagógus elbátortalanodik, hogy nehezebb helyzetben lévő diákokat tömörítő intézményben vállaljon munkát. Az NLCB felülvizsgálata ugyan megtörtént a kötet elkészültét követően, és átadta helyét az Every Student Succeeds törvénynek, azonban ez nem hozott jelentős változást a teljesítményorientált szemléletben. $\mathrm{Az}$ iskolák továbbra is kötelesek részt venni az éves mérésekben, de az államok nagyobb egyéni autonómiát kaptak az elvárások kijelölésében és betartatásában.

A szerzők háromféle prevenciós programot különböztetnek meg: általános, irányított, javallott. Az általános prevenciós programok tág célcsoporttal rendelkeznek: előzetes kockázatok figyelembevétele nélkül bármilyen diákot felvesznek. Ez az univerzális megközelítés a nem kívánt viselkedés kialakulásának megelőzése vagy késleltetése érdekében olyan információk átadását és készségek fejlesztését helyezi előtérbe, amelyek minden diák számára egyaránt hasznosak (pl. szocioemocionális tanulást segítő programok: Respect and Responsibility Program, The Humanware Initiative, Promoting Alternative Thinking Strategies). Ezzel szemben vagy épp emellett az irányított prevenció kifejezetten olyan diákokkal való közös munkát jelent, akiknél valamilyen okból kifolyólag na- gyobb az esélye a nem kívánatos viselkedési formák megjelenésének, akik tagjai egy vulnerábilis csoportnak (pl. iskolából kimaradók: Reconnecting Youth). A javallott prevenció pedig azokra irányul, akiknél már meg is jelent a viselkedés és a cél annak folytatásának elkerülése.

$\mathrm{Az}$ elsődleges típusválasztáson túl további univerzális szempontok vezérelhetik az iskolákat a programok tervezésekor: az intézmény szervezeti működésével való összeegyeztethetőség, egyszerű használhatóság. Rohrbach és Dyal szerint a pedagógusok számára meghatározó, hogy tartozik-e a programhoz részletes és könnyen olvasható kézikönyv, mennyire ismerős a módszertani eszköztár számukra, a már gyakorlatban lévő tanmenethez képest van-e többletértéke, illetve hozzáférhetőek-e előkészített audiovizuális tartalmak. Mivel a programok elsődleges megvalósítói a pedagógusok, esetleg iskolapszichológusok, szociális munkások és nem prevencióspecialisták, az USA-ban uralkodó teljesítményorientált környezet arra sarkallja a programok kiválasztóit, hogy a kevés befektetéssel járó opciót keressék. A ráfordítandó idő, pénz és emberi erőforrás szükösségének fontossága pedig nő azzal, hogy a sztenderdnek való megfelelés vezérli az iskolák hétköznapi müködését.

A vezetőség feladata, hogy felmérje, a különböző programok mennyire illeszkednek az iskola szükségleteihez, illetve fordítva: felfedezni, hogy a felmerülő igényekre fejlesztettek-e már eredményesnek bizonyított gyakorlatot. Meghatározó szerepet töltenek be a megvalósítás közben is azáltal, hogy a prevencióval kapcsolatos kommunikációjukban mire helyezik a hangsúlyt, hogyan szervezik a csatlakozó tanárok terheltségét, és mennyire hajlandóak irányelveiket, szabályzataikat alakítani a program által meghatározott célok mentén. A kötet több szerzője is kiemeli, 
hogy a bevezetési folyamat minőségét javítja a megvalósítóknak nyújtott segítő szolgáltatások igénybevétele: felkészítő tréning, coaching, programhüség monitorozása. Online támogató szolgáltatásra példát nyújthat az agresszív viselkedést csökkentő Good Behavior Game program. Ezen szolgáltatások hosszú távú biztosítása növeli a program hatékonyságát, és teret enged a kutatói együttmüködéseknek.

A fejlesztők, hatásvizsgálatot végző kutatók számára fontos tanulság, hogy a sikeres közös munkának alapja a bizalmi légkör megteremtése és a kölcsönös, hatékony kommunikáció. Elég időt és energiát kell szánniuk a kapcsolatok kiépítésére, akár a lokális összejöveteleken való részvétellel, a helyi változások nyomon követésével, a kapcsolati hálókat könnyen mozgósító résztvevők fellelésével. Azonban Testa és Coleman szerint úgy tűnik, a kutatók általában alábecsülik ezen kezdeti lépésekre szánt időt. A prevenciós program bevezetésekor hasznos, ha a kutatók bemutatják az iskola vezetésének, miért fontos az érintett téma az adott iskolának, hogy milyen eredmények mutatják a program eredményességét és megbízhatóságát. Az intézményvezetők elköteleződése nemcsak a program megvalósítása szempontjából esszenciális, de a rendszeres mérések és visszacsatolások miatt is. Meghatározott időközönként érdemes a kutatóknak összefoglalni az eredményeket és a felmerülő nehézségeket.

$\mathrm{A} z$ őszinte és bírálatmentes kommunikációt tovább erősítheti, ha az iskola vezetősége bármikor közvetlenül elérheti a koordinátort és probléma esetén gyors választ kaphat, a kutatók viszont nem keltik a siettetés látszatát. Az adatfelvételeket érdemes az iskolai elfoglaltságokhoz igazítani és elkerülni a vizsgákra, megemlékezésekre és tervezhető elfoglaltságokra való felkészülést. Megkönynyítheti az osztályokkal való kooperációt a nyugdíjas tanárok bevonása, míg a publikus adatok lekérése értékes információként szolgálhat. A megvalósítók és kitöltők honorálása ambivalens megítélésű: a motiváció fenntartásának kihívására ugyan választ ad, de nem feltétlen biztosítja a programhüséget, az erőforrások szűkösségekor pedig járhatatlan út.

A kutatók által fejlesztett prevenciós programok a legtöbb esetben könnyített közegben kerülnek kipróbálásra, ez más kontextusokban nem kedvez az elvárt eredmények elérésében. LaFromboise és Hussain szerint azonban az, hogy az amerikai diákközösségek kulturális összetétele évtizedről évtizedre diverzebb képet mutat, viszont a tanárok többsége változatlanul fehér középosztálybeli, eddig figyelem nélkül maradt. Ez a diszkrepancia egyaránt nehézséget okozhat az iskolák mindennapos működésében és a prevenciós programok hatékonyságában, mivel a kulturális sokszínűség növekedését a tanmenetfejlesztések sem követik nyomon. A szerzők szerint a prevenciós folyamatoknak, a gyakorlatok hatásmérésének igazodnia kell a sikeresség érdekében.

A tradicionális tanmenetalapú prevenciós beavatkozások alacsony hatásfokára adott válaszként jelent meg a teljes iskola megközelítés (whole-school approach). Az oktatási intézmény egészére vonatkozó stratégiák elve mentén a speciális tanórákon és a készségfejlesztésen túl fontos, hogy az iskola minden színterén valósuljanak meg a megelőző szemlélet elméleti sarokkövei. Hosszú távú hatás eléréséhez szükséges az eljárásrendek, rutingyakorlatok és az iskolai közösséghez tartozó összes felnőtt viselkedésének reflektív felülvizsgálata. A szerzők szerint a pozitív iskolai klíma biztonságérzetet és támogatottságot eredményez. Gyakorlatban sikeresen megvalósuló teljes iskolát érintő programként tartják számon a Gatehouse és a Healthy School Ethos Projectet. A sike- 
res, teljes iskolát érintő programok ugyan hasznosítják a hatékonyságot növelő tényezők legtöbbjét, mégsem küszöbölik ki a fenntarthatóságból fakadó nehézségeket.

Az erőforrások alkalmisága megszabja a programok várható élettartamát azáltal, hogy a pályázati pénzek elfogyását és a projekt lezárultát követően a megváltozott működés erőforrás hiányában hajlamos visszarendeződni. A rövid távon nem látszódó, de hosszú távon várt hatások helyett gyors válaszokat keresnek az intézményi müködés döntéshozói (pl. Drug Abuse Resistance Education), és igyekeznek inkább megfelelni az elkerülhetetlen központosított elvárásoknak. A hosszú távú elköteleződés fenntartásában segíthet a résztvevők folyamatos bevonása a döntési folyamatokba, a közösen alakított koordinációs bizottság létesítése (pl. Olweus Bullying Prevention Program). A megvalósító visszajelzéseinek megfelelően változtatható a programbeli tevékenység. Amellett, hogy a programot végrehajtó pedagógusnak a bevonás következtében nő az elköteleződése, az intervenciót is fejleszti a reflexiók beépítése.

A Kris Bosworth által szerkesztett tanulmánykötet kiemelendő értéke, hogy ugyan amerikai példákat mutat be, de gazdag, jó gyakorlatok gyüjteményének is tekinthető. Az olvasó akaratlanul is a hazai oktatáspolitikával, projektalapú finanszírozással és meglévő gyakorlatokkal állítja párhuzamba a szerzők tapasztalatait. Érdemes még a megelőző szemlélet gyakorlati megvalósításán dolgozni.

A cikk a Creative Commons Attribution 4.0 International License (https://creativecommons.org/licenses/ by/4.0/) feltételei szerint publikált Open Access közlemény, melynek szellemében a cikk bármilyen médiumban szabadon felhasználható, megosztható és újraközölhető, feltéve, hogy az eredeti szerző és a közlés helye, illetve a CC License linkje és az esetlegesen végrehajtott módosítások feltüntetésre kerülnek. (SID_1) 